\title{
SOFT SKILLS INTEGRATED LEARNING MODEL IN ELECTRONIC PRACTICE COURSES IN HIGHER EDUCATION
}

\author{
HASANAH $^{1}$, PURNAMAWATI ${ }^{2}$, MARWA ${ }^{3}$ \\ ${ }^{1,2}$ Faculty of Engineering, State University of Makassar, Indonesia \\ ${ }^{3}$ Graduate School State University of Makassar, Indonesia
}

\begin{abstract}
Mastery of soft skills for students is very important and very much needed by graduates so that they are able to survive and compete in facing various work challenges. The purpose of this research is to produce an integrated learning model of soft skills that is valid and effectively used in tertiary institutions. This type of research is Research and Development (R\&D) by following the ADDIE development stages (Analysis, Design, Development, Implementation, and Evaluation). The development of an integrated learning model for soft skills integrates soft skill attributes, namely: discipline, communication, creativity, cooperation, honesty, detail-oriented, polite and be confident. The research subjects were students of the Diploma Three (D3 Vocational) program of the Muhammadiyah Makassar Institute of Electromedical Engineering who took the Electronics Practice course, in the even semester of the 2018/2019 academic year totaling 29 students. The results of the study are: (1) After going through validation and product testing, the result is that the integrated learning soft skill model is valid for use in electronic practical learning; (2) The syntax of the integrated soft skills learning model developed by integrating 8 attributes of soft skills into the learning syntax, namely: discipline, communication, creativity, cooperation, honesty, detail-oriented, polite, and self-confident, can be carried out well so that it can be concluded. that the model developed is practically used in practical electronics learning; and (3) The test results are extended to the integrated learning model of soft skills in Electronics practical courses which are developed to effectively improve the soft skills of students based on observations of student activities and responses to the model.

KEYWORDS: Learning Model, Soft Skills, Syntax, Effective
\end{abstract}

Received: Jun 08, 2020; Accepted: Jun 28, 2020; Published: Sep 18, 2020; Paper Id.: IJMPERDJUN20201320

\section{INTRODUCTION}

In the current era of globalization, Indonesia is faced with two challenges, namely: the first challenge is the presence of the fourth industrial revolution (RI 4.0) which is now taking place. There is no driving factor for the change in world civilization as strong as the industrial revolution that has resulted in technological progress. Due to technological advances, the world is changing so fast. The second challenge is globalization, especially the enactment of the ASEAN Economic Community (AEC). The era of the free market in the ASEAN economic community (AEC) currently requires universities to be able to produce competitive graduates who can compete with graduates from various countries. It is hoped that the success of higher education institutions in Indonesia in producing quality graduates so that many government policies are in favor of improving the quality of graduates. However, the quality of Indonesia's human resources (HR) is still low based on a report from the UNDP (United Nations Development Program) in 2019, which is seen from the Human Development Index (HDI), Indonesia is ranked 111th from 189 countries. When viewed from the structure of the Indonesian workforce, according to data 
from the Central Bureau of Statistics (BPS, 2019), the total number of open unemployed people as of February 2019 was $6,816,840$, with the contribution of unemployment from universities, namely: from academies/diplomas of 269,976 (3, $96 \%)$ and the University of $839,019(12.3 \%)$.

This phenomenon illustrates that the readiness of workers in Indonesia is still low which will be left behind with other ASEAN countries. Therefore, one of the government policies to oversee and develop the competence and work readiness of college graduates is the revitalization of vocational education. Vocational education revitalization is one of the efforts taken by the Government to improve the quality of human resources, which is one of the most important determining factors in achieving the success of development programs. Quality human resources will be able to manage other resources properly and efficiently. A competitive and skilled workforce, one of which is born from quality vocational education and is relevant to the demands of the constantly developing world of work. Thus, the world of education must also keep up with the changing times (Ministry of Education and Culture, 2016)

Higher Education (PT) is an educational unit that prepares graduates to master science and competence according to their field of knowledge, where college graduates do not only master hard skills, but must master soft skills as a strengthening of academic intelligence so that they are more able to work productively and quality. Therefore, these two abilities are the key to the success of college graduates to compete in the world of work.

According to Wagner (2008), there are seven skills so that a person is able to survive in the new world order, namely: (1) critical thinking and problem-solving; (2) collaboration across networks and leading by influence; (3) agility and adaptability; (4) initiative and entrepreneurialism; (5) effective oral and written communication; (6) accessing and analyzing information; and (7) curiosity and imagination. Of the seven skills mentioned by Wagner (2008) above, all are soft skills. That is, soft skills are very important for someone to have. Soft skills are characteristic abilities possessed by individuals in responding to their environment. According to Robles, (2012) that soft skills are an intrapersonal quality or characteristic abilities that workers have that have nothing to do with technical knowledge, for example, the ability to interact with other people and adaptability.

Soft skills are interpersonal skills such as how individuals establish relationships or interact with other people and intrapersonal skills such as the ability to manage themselves (Cimatti, 2016). Mastery of soft skills for students is very important and very much needed by graduates so that they are able to survive and compete in facing various work challenges (Quieng et al., 2015). This ability is the key that makes students able to work together as reliable team members, solve work problems appropriately and appropriately, communicate effectively to build performance, increase work productivity and develop efficient and effective thinking patterns (Tavčar et al., 2005; Renaldi, 2020). Soft skills as a characteristic of a person can be seen clearly in their career development, and are clearly needed to build success and work success (Bedwell et al., 2014; Nurmila, 2020).

Several studies on the importance of soft skills in the workplace. Klaus (2010) found that long-term work success is determined by $75 \%$ by people skills while the remaining $25 \%$ is determined by technical knowledge. Furthermore, Watts \& Watts, (2008) in John (2009) stated that soft skills contributed to the success by $85 \%$ while hard skills only contributed $15 \%$. In addition, employers are progressively looking for employees with good social skills, they place soft skills in an important place in job success (Wilhelm, 2004). Asmuni's research results (2015) state that the quality of soft skills for communication skills is at the top with a score of 4.69 then honesty is second with a score of 4.59 , the ability to work together with a score of 4.45 , Interpersonal ability with a score of 4,5 , a good work ethic is at a score of 4.46 , has a 
motivation of 4.42, is able to adapt at a score of 4.41, self-confidence is at a score of 3.95 , creative is 3.59 . Based on the study of the results of this research, the ability of soft skills is very important for tertiary education graduates, however, graduates need to have hard skills abilities. These two abilities, both soft skills and hard skills, are two abilities that university graduates must have to be able to compete in the world of work (Asmuni, 2015; Patacsil \& Tablatin, 2017).

Furthermore, the results of research by Widarto \& Widodo (2012) show that company leaders assess the aspects of knowledge, skills, character/attitudes, and the physical condition of employees to produce the highest quality products are attitude $(28,33 \%)$, physical condition $(26,33 \%)$, knowledge (23\%) and skills $(23.33 \%)$. This proves that the aspect of attitude (soft skills) is very important to be developed in students.

Soft Skills are the main step in entering the world of work, so it is necessary to develop an integrated learning model for soft skills. Based on the study of several research results, it is very important that the integration of soft skills values in learning, especially practical learning, to improve student competence and readiness to enter the world of work, because learning patterns in practical courses so far have focused more on mastering hard skills alone and less give a portion to the effort to develop soft skills.

Saillah (2008) states that the ratio of the need for soft skills and hard skills in the business world and the industrial world is inversely proportional to the existing development in the education system. In the current education system, soft skills are only given an average of $10 \%$ in the curriculum (Suryanto, 2013).

The demand for relevance between the world of education and the world of work is the mastery of a number of competencies that must be demonstrated and demonstrated at work, especially for vocational education graduates. Vocational education is education that prepares graduates to master science and connects skills and attitudes with work values (positions), especially those related to the skills needed by the world of work. (Kuswana, 2013: 157).

These findings are in line with research by Robles (2012) which states that there are ten attributes of soft skills most needed by the world of work based on business executive perceptions, namely: (1) integrity, (2) communication, (3) politeness, (4) responsibility, (5) interpersonal, (6) professionalism, (7) positive attitude, (8) teamwork, (9) flexibility, and (10) work ethics. So it is very clear that the ability of soft skills is needed and plays an important role in the success of the workforce in the industrial world. Therefore, it is necessary to develop a learning model that is integrated with the values of soft skills with all courses. In this research, will develop an integrated learning model of soft skills in Electronics practice courses at the Muhammadiyah Makassar Academy of Electrical Engineering (ATEM). Muhammadiyah Makassar Academy of Electromedical Engineering is one of the Vocational Education in Makassar City.

\section{METHODS}

This type of research is Research and Development (R\&D). Research and Development methods are used to produce certain products and test the effectiveness of these products. This study uses the ADDIE (Analysis, Design, Development, Implementation, and Evaluation) development model. Developing an integrated learning model of soft skills in practical learning by integrating soft-skill attributes, namely: (1) discipline, (2) communication, (3) creativity, (4) cooperation, (5) honesty, (6) detail-oriented, (7) ) polite and (8) confident.

The integrated learning model of soft skills in practical courses is designed in such a way as to provide an overview of the learning development process in achieving the goals to be achieved, this model is designed to provide strengthening understanding in carrying out the learning process for college lecturers to make it easier to integrate the 
values of soft skills in learning. The integrated learning model for soft skills in electronics practice courses at ATEM Muhammadiyah Makassar is shown in Figure 1.

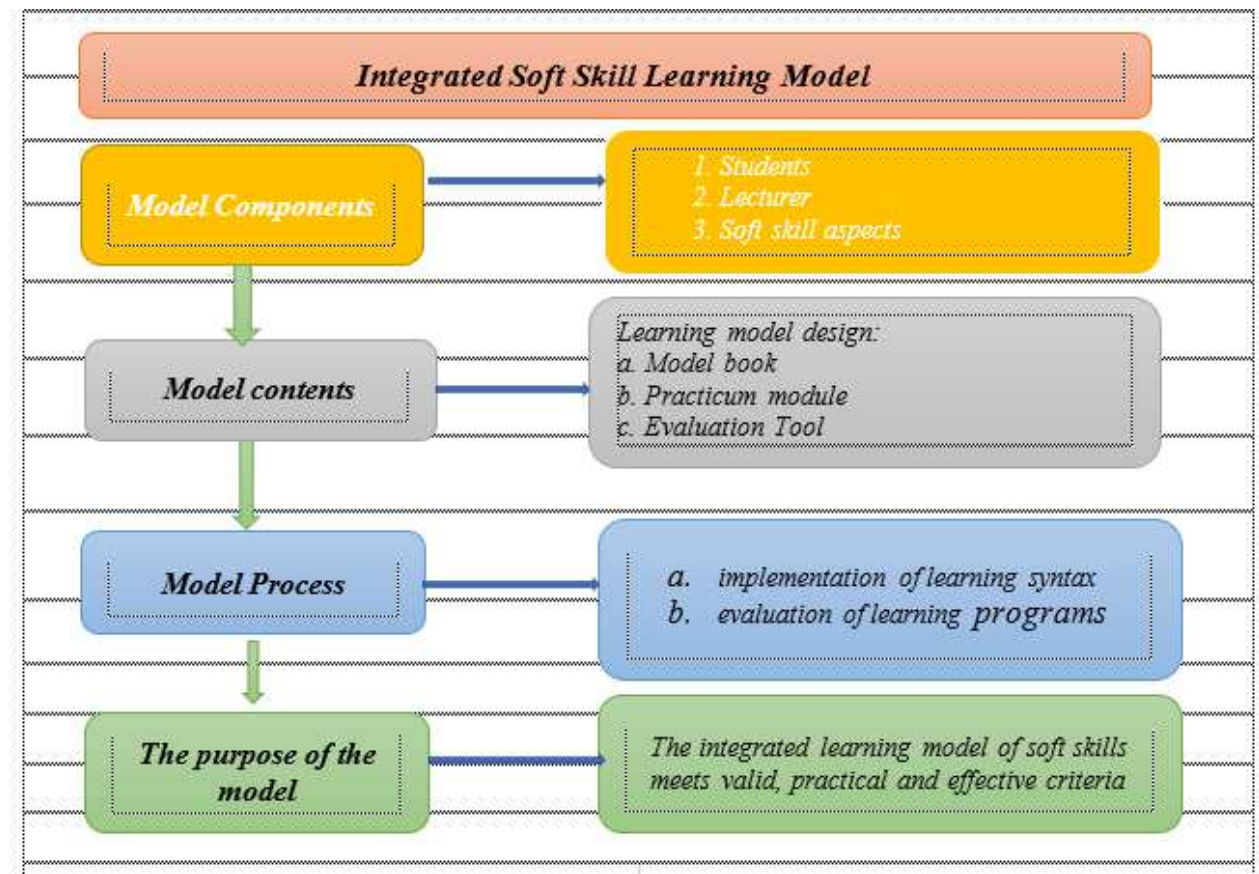

Figure 1

\section{Soft Skill Integrated Learning Model}

The conceptual model of integrated learning soft skills in electronics practice courses consists of attributes of soft skills, namely: discipline, communication skills, creativity, ability to work together, honesty, detail-oriented, polite and confident in each Learning Outcome (CP) in the course electronic practice, such as (1) 1st learning outcomes integrate soft skills: detail-oriented, discipline, confidence and communication, (2) 2nd learning outcomes integrate soft skills: discipline, creativity, collaboration, and confidence, (3) the 3rd learning outcomes integrate soft skills: honesty, polite, discipline, creativity, collaboration and focus on details, (4) the 4th learning sub-achievement integrates soft skills: discipline, cooperation, creativity and focus on detail.

The structure of the soft skills integration model in electronics practice courses can be seen in Figure 2. 


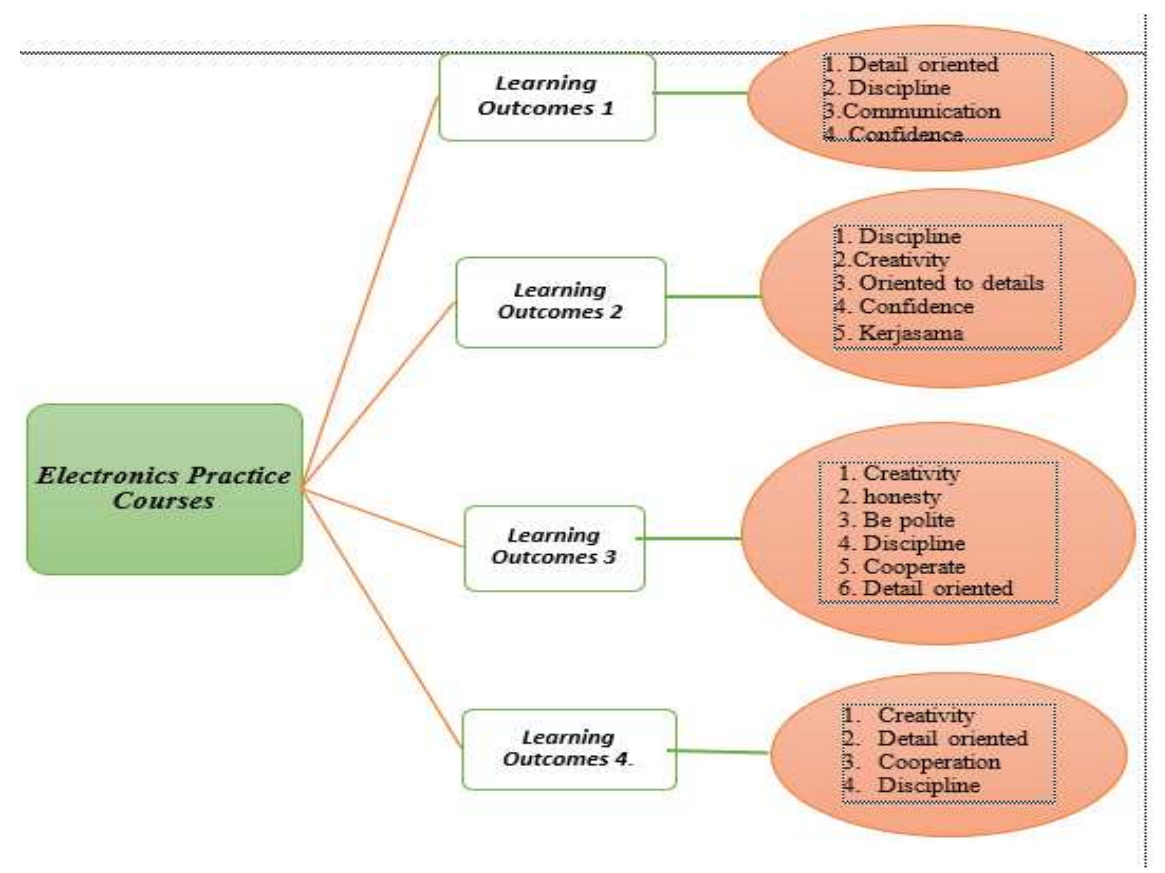

Figure2: The structure of the model of integrated soft skills in electronic practice courses

The research subjects were students of the Diploma Three (D3 Vocational) program at the Muhammadiyah Makassar Academy of Electromedical Engineering. The number of respondents in this study were 29 students who took the Electronics Practice course, the subject of the product readability trial consisted of 7 students who were taken randomly. While the small group trial was taken as a whole of the respondents. The data analysis technique used is descriptive analysis techniques and descriptive statistics in the form of data presentation in the calculation of mean and percentage tables. The data were analyzed by calculating the average answer based on the score for each answer from the respondent.

The criterion used to decide that an instrument has an adequate degree of validity is if the mean (M) of the research results for all aspects at least is in the 'valid' category.

Table 1: Validity Categories

\begin{tabular}{|c|l|}
\hline Interval & \multicolumn{1}{|c|}{ Category } \\
\hline$>4,51 \mathrm{~s} / \mathrm{d} 5,0$ & Very valid \\
\hline$>3,41 \mathrm{~s} / \mathrm{d} 4,50$ & Valid \\
\hline$>2,61 \mathrm{~s} / \mathrm{d} 3,40$ & Valid enough \\
\hline$>1,81 \mathrm{~s} / \mathrm{d} \mathrm{2,60}$ & Less valid \\
\hline $1,00 \mathrm{~s} / \mathrm{d} \mathrm{1,80}$ & Not valid \\
\hline
\end{tabular}

Source: Widoyoko (2016)

The criterion used to decide that an instrument has an adequate degree of validity is if the mean (M) of the research results for all aspects at least is in the 'valid' category. If the instrument that has been made is not valid, then a revision is made based on suggestions from the validator or by looking back at the aspects that are considered insufficient. Then re-validated and then analyzed again. Thus, if the minimum average value is under the valid category, revision is made to the valid category. 
Practicality analysis is expressed through instrument items that are given to the subject group in field trials or expanded. The level of practicality of learning devices is obtained from user/lecturer responses and student responses which are expressed through instrument items based on the results of lecturer and student activities in integrated soft skills learning in Electronics practice courses. To state the practical status of the development of integrated soft skills learning in practical learning, observation data, student and lecturer responses are used with the categories of division as in Table 2.

Table 1: Practicality Categories

\begin{tabular}{|c|l|}
\hline Interval & \multicolumn{1}{|c|}{ Category } \\
\hline$>4,51 \mathrm{~s} / \mathrm{d} 5,0$ & Very practical \\
\hline$>3,41 \mathrm{~s} / \mathrm{d} 4,50$ & Practical \\
\hline$>2,61 \mathrm{~s} / \mathrm{d} 3,40$ & Practical enough \\
\hline$>1,81 \mathrm{~s} / \mathrm{d} 2,60$ & Less practical \\
\hline $1,00 \mathrm{~s} / \mathrm{d} 1,80$ & Not practical \\
\hline
\end{tabular}

Source: Widoyoko (2016)

The level of effectiveness of learning devices is taken from observations of student activity data and learning outcomes, namely observations made by lecturers in electronics courses. At the beginning of the lecture activity until the end, it was analyzed using descriptive analysis, namely the presentation with the categories as in Table 3

Table 3: Effectiveness of Categories

\begin{tabular}{|c|l|}
\hline \multicolumn{1}{|c|}{ Interval } & \multicolumn{1}{|c|}{ Category } \\
\hline$>4,51 \mathrm{~s} / \mathrm{d} 5,0$ & Very effective \\
\hline$>3,41 \mathrm{~s} / \mathrm{d} 4,50$ & Effective \\
\hline$>2,61 \mathrm{~s} / \mathrm{d} 3,40$ & Effective enough \\
\hline$>1,81 \mathrm{~s} / \mathrm{d} 2,60$ & Less effective \\
\hline $1,00 \mathrm{~s} / \mathrm{d} 1,80$ & Ineffective \\
\hline
\end{tabular}

Source: Widoyoko (2016)

\section{RESULTS AND DISCUSSIONS}

Development of an integrated learning model for soft skills in electronics practice courses in tertiary institutions. The development of the integrated soft skills learning model in this study is structured based on the ADDIE development research sequence (Analysis, Design, Development, Implementation, and Evaluation with the following stages:

\section{Analysis Phase}

Needs analysis is the initial stage in the process of developing a learning model. The needs analysis stage consists of a literature review, student analysis, and concept analysis. The analysis aims to analyze the need for the development of integrated soft skills in learning and to analyze the feasibility and requirements for the development of integrated soft skills which consists of needs analysis, literature review, and development of a conceptual framework.

\section{Design Stage}

This stage includes the preparation of the initial design of the learning device, namely: the preparation of tests, determining the models, methods, and instruments used to assess the quality of the learning tools, and the process of validating the 
learning tools. The learning development model produces Semester Learning Plans (RPS) products, Learning Events Units (SAP), practicum modules, model books, and evaluation tools to be realized or tested. At this design stage, an evaluation of the soft skills integrated learning model is also carried out. Evaluation at this stage is to validate products that have been made by involving 2 (two) experts to assess and validate the products and instruments that have been made so that weaknesses and shortcomings can be known and get data about the results of products that have been made for later revision.

\section{Development Stage}

Based on the development steps, the implementation at this development stage will be tested, namely (1) peer evaluation (one to one), (2) small group trials, (3) expanded trials. This trial was conducted to produce an opinion regarding the feasibility of the learning model being developed. A summary of peer assessments about the product of the integrated soft skill learning model in the Electronics Practice course at the Muhammadiyah Makassar Electromedical Academy.

Table 4: Peer ratings of products

\begin{tabular}{|c|l|c|l|}
\hline No & \multicolumn{1}{|c|}{ Scoring Criteria } & Average & \multicolumn{1}{c|}{ Categories } \\
\hline 1 & Semester Lesson Plan & 4,80 & Very good \\
\hline 2 & Learning Program Unit & 4.47 & Good \\
\hline 3 & Model Book & 4,50 & Good \\
\hline 4 & Practice Module & 4,50 & Good \\
\hline 5 & Evaluation Device & 4,50 & Good \\
\hline & Average & 4.55 & Very good \\
\hline
\end{tabular}

Source: results of data analysis (2019)

Based on the data in Table 4, it is found that the total average value of peer assessments of learning devices obtained an average value of 4.55 indicating that the learning tools developed are in the very good category.

The next trial is the small group trial. At this stage, the trial was carried out by taking the whole number of respondents. The implementation procedure is to distribute practicum modules and questionnaires. The trial was conducted by involving students and lecturers as users of this learning model. This trial was conducted to evaluate the product in the form of a practicum module.

Table 5: Results of the Practice Module Trials (small group trials)

\begin{tabular}{|l|l|c|l|}
\hline No & \multicolumn{1}{|c|}{ Rated aspect } & Average & \multicolumn{1}{c|}{ Category } \\
\hline 1 & Module Format & 4,35 & Good \\
\hline 2 & Language & 4.47 & Good \\
\hline 3 & Module Contents & 4,41 & Good \\
\hline & Average & 4,41 & Good \\
\hline
\end{tabular}

Source: Results of data processing (2019)

Based on Table 5, overall in the three aspects of the assessment, it gets a total average of 4.41 and is in a good category. Therefore it can be concluded that the overall aspects of this group trial are in good criteria with a few minor revisions. The results of these improvements were then used for trials on more trial subjects, namely in wider trials.

\section{Implementation Stage}

The implementation stage is an expanded trial phase which is carried out by taking all students who take the Electronics Practice course to provide their comments or opinions on the learning module being developed. The Test Results are extended to the Practice Module, as in Table 6 below. 
Table 6: Results of the Practice Module Trial (expanded trial)

\begin{tabular}{|l|l|c|l|}
\hline \multicolumn{1}{|c|}{ No } & \multicolumn{1}{|c|}{ Rated aspect } & Average & \multicolumn{1}{c|}{ Category } \\
\hline 1 & Module Format & 4,55 & Very Good \\
\hline 2 & Language & 4.66 & Very Good \\
\hline 3 & Module Contents & 4,55 & Very Good \\
\hline & Average & 4,59 & Very Good \\
\hline
\end{tabular}

Based on Table 6 as a whole, the three aspects of the assessment get a total average of 4.59 and are in the very good category. Therefore it can be concluded that the overall aspects of the expanded trial are in very good criteria.

\section{Evaluation Stage}

At the time of implementing the integrated soft skills Learning Model in the Electronics Practice course class, an evaluation was carried out by observing learning activities for 2 meetings, based on the indicators of the soft skills developed consisting of 8 aspects, namely: (1) discipline, (2) ability to communicate, ( 3) Ability to work together, (4) Creativity, (5) Honesty, (6) Detail-oriented, (7) Polite, and (8) Confidence.

The results of the evaluation of the soft skills of students after the application of this Learning Model can be seen in Table 7 below.

Table 7: Results of the evaluation of students' soft skills abilities

\begin{tabular}{|l|l|l|l|l|l|}
\hline \multirow{2}{*}{ No } & \multirow{2}{*}{ Soft Skills aspect indicator } & \multicolumn{2}{c|}{ Meeting I } & \multicolumn{2}{c|}{ Meeting 2 } \\
\cline { 3 - 6 } & & & Criteria & & Criteria \\
\hline 1 & Discipline & 4.2 & Good & 4.9 & Very Good \\
\hline 2 & Communication skills & 3.7 & Good & 4.7 & Very Good \\
\hline 3 & The ability to work together & 3.7 & Good & 4.7 & Very Good \\
\hline 4 & Creativity & 3.1 & Enough & 4.1 & Good \\
\hline 5 & Honesty & 3.5 & Good & 4.2 & Good \\
\hline 6 & Detail-oriented & 3.5 & Good & 4.2 & Good \\
\hline 7 & Polite & 4.3 & Good & 4.7 & Very Good \\
\hline 8 & Confidence & 4.3 & Good & 4.7 & Very Good \\
\hline & Average & 3.79 & Good & 4.53 & Very Good \\
\hline
\end{tabular}

Source: Results of data processing (2019)

Based on the percentage of the results of the evaluation of students' soft skills abilities in Table 7, that the overall indicators at the first meeting obtained an average total of 3.79 which indicates that the results of the evaluation of the soft skills of students at the first meeting are in good criteria, while the overall indicators at the second meeting are obtained on average. a total of 4.53 which indicates that the results of the evaluation of students' soft skills abilities at the second meeting were in very good criteria. This means that the Integrated Learning Model of soft skills in electronic practice learning at ATEM Muhammadiyah Makassar is effective in improving the soft skills of students. The increase in the soft skills of students from the first meeting with good criteria increased significantly at the second meeting with very good criteria. The Complete can be seen in Figure 3 below. 


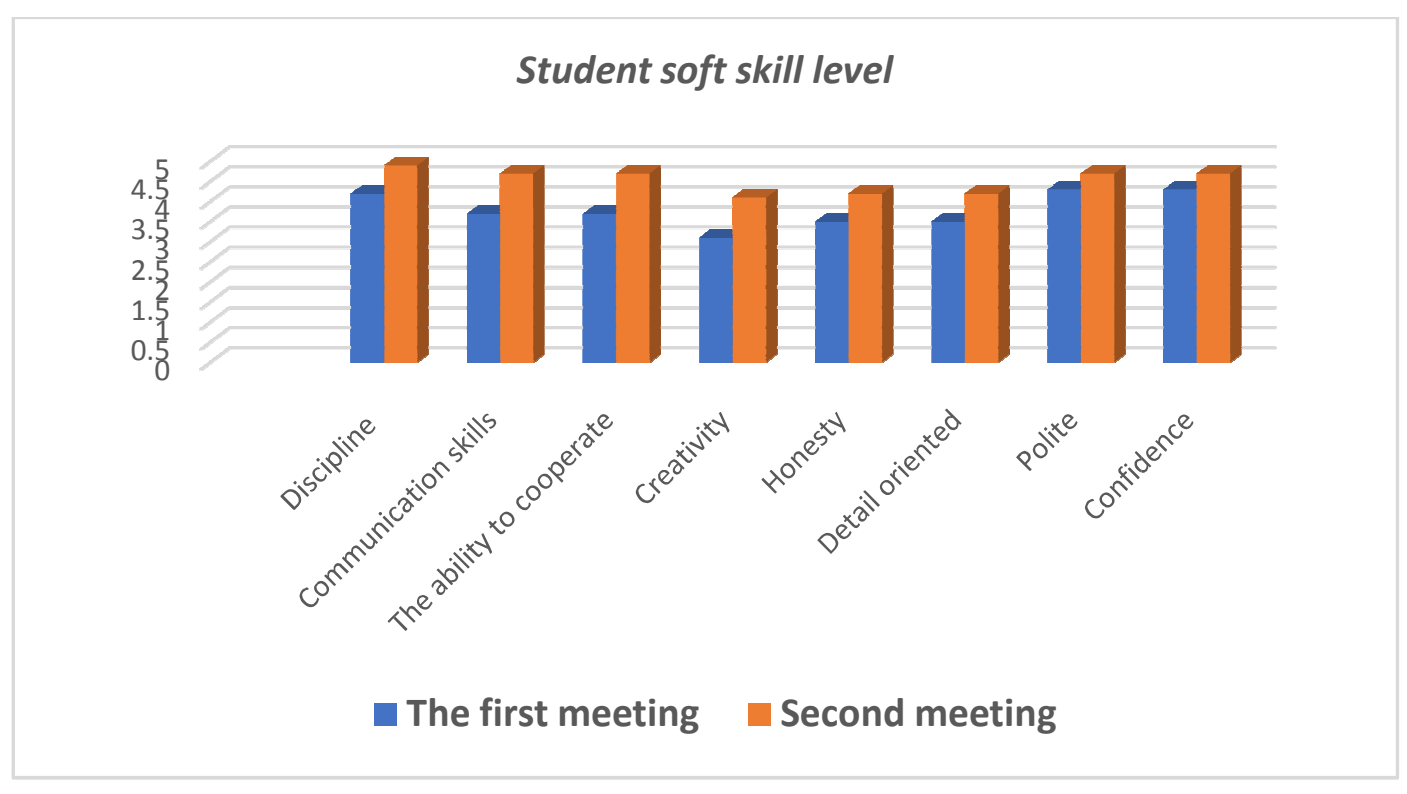

Figure 3: Ability level of student soft skills

Based on the results of these studies, the soft skills aspect of discipline is in the highest criteria, then communication skills, cooperation skills, politeness, and self-confidence are also very good. This is supported by the research of Widarto \& Widodo (2012) that the aspects of soft skills needed by the world of work are discipline, courtesy, communication skills, cooperation, honesty, self-confidence, responsibility, creativity, and leadership. Furthermore, the research results of Suryanto et al. (2013) produced the relevance of soft skills needed by the business/industry world and those taught in Vocational High Schools according to teachers and students, namely: (1) honesty and good behavior, (2) a sense of responsibility, (3) time discipline, (4) work safely, (5) tough/persistent in working. Therefore, it can be concluded that the integrated soft skill Learning Model developed is effective in improving the soft skills of students in tertiary institutions.

\section{CONCLUSIONS}

The stages of developing soft skills integrated learning model in practical courses that aim to improve students' soft skills starting with a preliminary analysis, needs analysis, identification of learning objectives, student analysis, and concept analysis, then the design stage which includes composing tests, determining models, determine learning methods, and compile research instruments. In the development stage, the materials are prepared in learning tools that will be used in developing learning models which include the preparation of RPS, SAP, soft skills integrated model books, soft skills integrated practicum modules, and student soft skills evaluation tools. The preparation of the learning device produces an initial prototype that is validated by experts, improvements are made after input from experts. Then it was tested, and the final stage was evaluating. After going through validation and product trial testing, the result is an Integrated Learning model of soft skills that are valid for use in practical learning electronics. The syntax of the soft skills integrated learning model developed by integrating 8 attributes of soft skills into the learning syntax, namely: discipline, communication, creativity, cooperation, honesty, detail-oriented, polite, and confident, can be implemented well so that it can be concluded that the model used developed practically used in learning electronics practice. The test results were extended to the integrated soft skills learning model in the Electronics practical course which was developed to effectively improve the soft skills of students based on student activities and responses to the model. 


\section{REFERENCES}

1. Al Abduwani, T. A. (2012). The Value and Development of Soft Skills: The Case of Oman. International Journal of Information Technology and Business Management, 2(1), 87-88.

2. Asmuni. (2015). Pengembangan Softskills dan Karakter Mahasiswa untuk Menyongsong Masa Depan Cerah. Paper presented at the National Seminar of STKIP PGRI Jombang, September.

3. Badan Pusat Statistik Sumber. (2017). Survei Angkatan Kerja Nasional (Sakernas). Makassar: Badan Pusat Statistik.

4. Bedwell, W. L., Fiore, S. M., \& Salas, E. (2014). Developing the future workforce: An approach for integrating interpersonal skills into the MBA classroom. Academy of Management Learning \& Education, 13(2), 171-186.

5. Choudary, D. V., \& Ponnuru, M. (2015). The Importance of Soft-Skills Training for Mb Students and Managers. Abhinav International Monthly Refereed Journal of Research in, 4(11), 6-14.

6. Cimatti, B. (2016). Definition, development, assessment of soft skills and their role for the quality of organizations and enterprises. International Journal for quality research, 10(1).

7. Hamidah, S. (2012). Profil Soft skills Mahasiswa Pendidikan Teknik Boga (PTB) Fakultas Teknik Universitas Negeri Yogyakarta. Jurnal Pendidikan Vokasi, 3(2).

8. John, J. (2009). Study on the nature of impact of soft skills training programme on the soft skills development of management students. Pacific Business Review, 19-27.

9. Kementerian Pendidikan dan Kebudayaan. (2016). Revitalisasi Pendidikan Vokasi. Kementerian Pendidikan dan Kebudayaan Republik Indonesia.

10. Kementrian Republik Indonesia. (2015). Peraturan Menteri Riset Teknologi Pendidikan Tinggi. RI, No. 44 tahun 2015. Jakarta: Tentang Standar Nasional Pendidikna Tinggi. Kementrian Republik Indonesia.

11. Klaus, P. (2010). Communication breakdown. California Job Journal, 28(1248), 1-9.

12. Kuswana, W. S. (2013). Filsafat Pendidikan Teknologi Vokasi dan Kejuruan. Bandung: Alfabeta.

13. Nurmila, N. (2020). Improving the Students' Reading Skill Trough Note-Taking Technique: a Pre-Experimental Research. Journal La Edusci, 1(1), 25-32.

14. Patacsil, F. F., \& Tablatin, C. L. S. (2017). Exploring the importance of soft and hard skills as perceived by IT internship students and industry: A gap analysis. Journal of Technology and Science Education, 7(3), 347-368.

15. Quieng, M. C., Lim, P. P., \& Lucas, M. R. D. (2015). 21st Century-Based Soft Skills: Spotlight on Non-Cognitive Skills in a Cognitive-Laden Dentistry Program. European Journal of Contemporary Education, 11(1), 72-81.

16. Robles, M. (2012). Executive Perceptions of the Top 10 Soft Skills Needed in Today's Workplace. Business Communication Quarterly, 75(4), 453-465

17. Saillah, I. (2008). Pengembangan Soft Skills Dalam Proses Pembelajaran di Perguruan Tinggi. Tim Kerja KBK dan Soft Skills Ditjen Pendidikan Tinggi Bogor.

18. Suryanto, D., Kamdi, W., \& Sutrisno, S. (2014). Relevansi soft skill yang dibutuhkan dunia usaha/industri dengan yang dibelajarkan di Sekolah Menengah Kejuruan. Teknologi Dan Kejuruan, 36(2).

19. Tavčar, J., Žavbi, R., Verlinden, J., \& Duhovnik, J. (2005). Skills for effective communication and work in global product development teams. Journal of engineering design, 16(6), 557-576. 
20. Wagner, T. (2008). The Global Achievement Gap. New York: Basic Books.

21. Widarto, P., \& Widodo, N. (2012). Pengembangan model pembelajaran soft skills dan hard skills untuk siswa SMK. Cakrawala Pendidikan, 31(3), 409-423.

22. Widoyoko, E. S. (2016). Teknik Penyusunan Instrumen Penelitian. Yogyakarta: PT. Pustaka Pelajar.

23. Wilhelm, W. J. (2004). Determinants of moral reasoning: Academic factors, gender, richness of life experiences, and religious preferences. Delta Pi Epsilon Journal, 46(2), 105-123.

24. Renaldi, S. (2020). Using Instagram to Improve Students' Ability and Interest in Writing Descriptive Paragraph. Journal La Edusci, 1(1), 12-24. 

